HUBERT ALBERTUSIAK*

\section{Redukcjonistyczna koncepcja konstrukcji ramowej dla siedzisk}

\section{Reductionistic concept of frame structure for seats}

Streszczenie

Znaczną część wyposażenia wnętrz mieszkalnych i użyteczności publicznej stanowią obecnie meble przeznaczone do samodzielnego montażu. Nadanie te działania to próba stworzenia alternatywnego rodzaju konstrukcii, składającego sie z elementów przeznaczonych do bezpośredniego łacczenia. Wartościa akiego rozwizzania moie być uproscczenie sposobu scalania jaki i redukcja kosztów produkcii. Opracowany układ przystosowany jest do wytwarrania pray

Summary

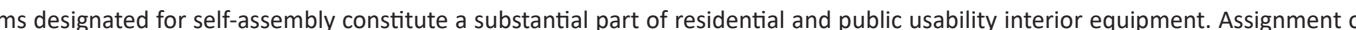
his value to popular types of wooden seats and stools became possible mainly due to the growing popularity of mechanical connectors. The undertake ctions constitute an attempt to create an alternative type of structure that consists of elements designated for direct connection. The value of such a sothion may thus be the simplification of the scaling method as well as reduction of production costs. The elaborated system is adjusted to production with
the use of CNC plotter. Prototypes the diversification of which reflects the potential concept universal nature have been realized within this technique.

Stowa kluczowe: projektowanie mebli, krzesto, stotek, meble do samodzi
Keywords: furniture designing, chair, stool, furniture for self-assembly

Wstęp

Od konca lat 80. XX wieku w architekturze i sztuce użytkowej występują silne tendencje redukcyjne. Dawniej powodowane ascezą, obojętnością na świat, obecnie związane z rewolucją w podejściu do kultury i techniki, stanowią idee nurtującą sztukę od zawsze [7]. Przyczyn popularności minimalizmu w sztuce można wyróżnic wiele. Podążając tokiem rozumowania, który przedstawił Alain de Botton w swojej książce "Architektura szczęścia" można dojśc do wniosku, że $W$ architekturze pojawia się to, czego brakuje nam w życiu - „[...] ludzie tęsknoty kieriją dię dzis [...] ku temu, co naturaln

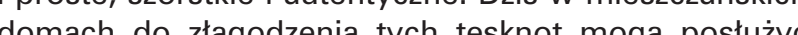
nicotynkone ściany i gote pustaki" [3. wyjaśnionie nasuwaja spostrzeżnia Adolfa Loosa, który upatrywat przyczyn zamitowania do bogatei formy min. w szacunku do nakładu pracy. Postawe taka przedstawi jako wroga rzemiosłu [6, s. 95]. Racjonalnym wydaje sie pogląd, według którego zaletą przedmiotu nie jest duż ilość pracy poświęconej na jego wykonanie. Naturalnie zwiększa to cene produktu, ale dzieje sie tak ze względu na koszty wykonania i nie należy tego utożsamiać z jakością samego przedmiotu. W przeciwnym razie o jego ocenie decydowałyby moce przerobowe fabryk i robotników. Odmiennie do czasów, w których tworzył Adolf Loos, proste formy przedmiotów sztuki użytkowej prze-

\section{ntroduction}

Since the late 1980s, there have been strong reduction trends in architecture and applied arts. Formerly caused by asceticism and indifference to the world and now connected with the revolution in the approach to culture and technology, they constitute the idea that has always bothered art [7]. There are many lowing the course of reasoning presented by Alain de Botton in his book "Architecture of happiness", one can come to the conclusion that in architecture there is what we lack in life - $-"$ [...] human longings are

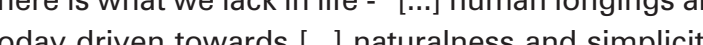
roughness and authenticity. Today, unpainted walls or bare blocks in the bourgeos hom un can beused to . ( cor in, e.g., respecling the work the we advantage of an item is not the large amount of work devoted to its production, seems to be rational. not be equated with the quality of the item itself. reasons for the popularity of minimalism in art. Folmin e.g.r respecting the workload. He presentod his Naturally, this increases the price of the product, but this is due to the cost of production and this should ważnie nie są już postrzegane jako ubogie choć przyczystawy, jaką prezentowal). W duzej mierze za zjawisko to odpowiada wysoki poziom efektywnosci wspołczesnych środków produkcji. Doprowadziło to do ogólnej dostępności seryjnie dekorowanych przedmiotów, co uczynito tworzenie wyrobów rzemieślniczych mało opłacalnym. To z kolei przyczyniło się do dewaluacji zdobnictwa. Silny związek sztuki użytkowej i technologii jest naturalny. W prezentowanej poniżej twórczości, będące przedmiotem badań, to właśnie konstrukcja i technik wykonania stanową o charakterze powstałych mebli i determinują ich formę. Uzasadnia to konieczność dale ko idącej ingerencji artysty $w$ procesy techniczne zwiazane zarówno z projektowaniem, jak i wytwarzaniem.

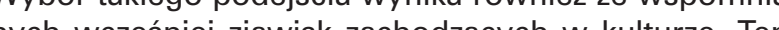
ych wczesnej zja sk zachodzacych w kutzurze. Tenge odbioy na inge cechy przedmiotu, niezwiazane tak ściśle z jego estetyka.

Jednym ze sztandarowych założeń przedstawianych Jedný ze sztarzarowych zalożh przéstawianych lyby sie w powszechnym użytkowani, Jost to dazenizbieżne z postawą współczesnego projektanta Jaspera Morrisona, który zacheca, aby produkować rzeczy codziennego użytku dla wszystkich; czynić je raczej lekkimi niż ciężkimi, raczej miękkimi niż twardymi, przystępnymi raczej niż ekskluzywnymi; generować energie, światto i przestrzeń" [10]. Tworzenie uniwersalnych rozwiazań, mogących znaleźć szersze zastosowanie, wiąże się również z tezą Victora Papanka, który podkreślał, że zasadniczą rolą designu jest ksztattowanie środowiska narzędzi człowieka, a przez to również jego samego [9, s. 45]. Projektowanie dla przemysłu wymaga szczegolnej rozwagi - wyprodukowane seryjnie przedmioty otaczają człowieka i nieustannie na niego oddziaływaja. Odmiennie natomiast funkcjonują dzieła sztuk plastycznych - kształtują ludzi w sposób bardziej impulsywny ispektakularny. Porownanie ich $z$ designem na tym polu każe rozumiec jego rolę jako sukcesywny wpływ na rzecz formowania poczucia estetyki. Stąd w prezentowanych autorskich dzialaniach przejawia się dążenie do stworzenia mebli będących przykładem efektywnego i minimalistycznego rozwiązywania problemów. Gdy I'Esprit roku Le Corbusier stworzył tymczasowy pawilo Esprit Nouveau na Międzynarodową Wystawę Sztul Dejo lowanie to szczególnie pasuje do określenia wrażonia jak moga wywotywać przedstawione w dalszej cześc artykułu prototypy.

$W$ prezentowanym projekcie podjete zostały starania o to, aby prostota dotyczyła wszystkich aspektów obiektu. Przykładem jest dażenie do uproszczenia procesu calania mebla - składanie elementów w catość po winno być intuicyjne, zajmować mało czasu i wysitku. Powinno być również bezpieczne dla samego przedmiotu, jak i dla użytkownika. Te istotne właściwości nie moga jednak zostać uzyskane kosztem skomplikowani produkcji, ponieważ i ona powinna być oszczędna. To z kolei wiąże się z koniecznością dostosowania projek-
Otherwise, the processing capacity of factories and times in which Adolf Loos created, simple forms of applied arts items are usually no longer seen as poor (although the reason for this is not the dissemination of the attitude he presented). To a large extent, this phenomenon is caused by the high level of effectiveness of modern means of production. This led to the general availability of serially decorated items, which made the creation of craft products unprofitwhle. This, in turn, contributed to the devaluation of ornamentation.

A strong connection between applied arts and technology is natural. In the work presented below, which is the subject of research, it is the structure and the technique of production that constitute the character fhe furniture and determine their form. This justifies the need for far-reaching artist's interference in technical processes related to both design and manufacturing. The choice of this approach also results from the aforementioned phenomena occurring in culture. The tendency to reject formalism necessarily transfers the recipient's attention to other features of the tem, which are not so closely related to its aesthetics. One of the flagship assumptions of the presented weserch is to create a furniture concept that would work well in general use. This aim coincides with the attitude of contemporary designer Jasper Morison, who encourages people to "produce everyday objects for everyone's use, make things lighter not heavier, softer not harder, inclusive rather than exclusive, generate energy, light and space" [10]. The creation of universal solutions that may be used more broadly is also connected with the thesis of Victor Papanek, who emphasized that the essential role of design is shaping the environment and the tools of a human, and thus also the human himself [9, p. 45] Designing for industry requires special consideration - mass produced objects surround people and con. On therty - they shape people in an

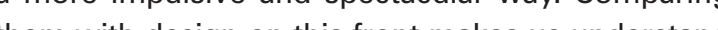
its role as a successive influence in favour of forming a sense of aeshetics. Hence, in the au of firmions prefor the problem solving. When in 1925 Le Corbusier created the tempory. When in 1925 Le Corbusier created ternational Exhibition of Decorative Arts in Paris, its interiors were jokingly called "provocatively simple" 11, p. 281. Thingly called "provocalivly suitable for de 284. This formulation is particulaly sutypes present in the furticle may give. 作 simplify all aspects of the facility. An example is the desire to simplify the process of assembling furniture 
tu do odpowiedniego narzędzia i redukcja ilości etapów produkcji. Umiarkowanie dotyczy równiez stosowania materiału. Ma to wiele korzysci: obniza cenę produktu, cenę transportu i magazynowania, czyni przedmiot ba dziej ekologicznym. Mniejsze zużycie materiału wpływa pozytywnie rownież na funkcjonalnośc mebla - staje się on Iżejszy. Minimalizm to coś więcej niż prosta forma nie świadczą o nim pozorne, powierzchowne działania. $\mathrm{Na}$ fakt, że brak dekoracji nie stanowi o minimalizmie zwraca uwage Janusz Krupiński: „W konkretnej sytuacj historycznej, gdy dekoracja czy ornament przyttoczyły przedmioty, być może trzeba było przypomnieć, że w ten sposób zagubiona została ich użyteczność. Tym niemniej, trudno za odkrywcza i specyficznie funkcjonalistyczną uznać niechęc do «bizantyjskiego przepychu»,

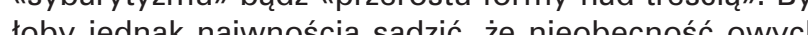
zjaw jek wy naizza by mówić o ze nzobecnośc owych zjawisk wystarcza, by mówic o ascetyzmie, purytanizmie

Conch jest opratome skutecznego oraz tatwa Stworzone rozwiązanie może okazać się przydatne nie wyobraźnię, jak pisał Rudolf Arnheim, można określić jako zdolność do nadania nowej formy starej treści [1, s. 150]. Uniwersalność prezentowanego schematu budowy ramy polega gównie na możliwości modyfikac przekrojów, proporcji oraz zmianie materiatów. Dzięki temu możliwa jest jej adaptacja w wielu rodzajach mebli i elementów wyposażenia wnętrz wykonanych $z$ drew na, materiałów drewnopochodnych, jak i tych wyciętych z arkuszy tworzywa sztucznego. Zastosowana metoda polega na tworzeniu i rozpatrywaniu prototypow oraz modeli w skali. Zarówno finalna idea konstrukcji, jak i powstale na jej bazie meble, zostaly zaplanowane tak, aby można było je wytwarzać seryjnie przy użyciu zaurodków produkcji, takich jak centrum obróbcze CNC.

\section{Koncepcja konstrukcji}

Przedstawione poniżej prototypy kwalifikują się do kate gorii RTA (ang. ready to assemble). Meble tego rodzaju zaczęły rozpowszechniać się $w$ drugiej połowie XIX wieku, głównie dzięki postępowi technicznemu, który umożliwił masową produkcję tanich łączników mechanicznych [12]. Ich stosowanie mialo istotny wplyw na Thonet czy IKEA bedacej obecnie liderem produkci meblide samodzienego montażu Omawian prototypy, w odróżnieniu od wiekkszości podobnych produktów wiodacych firm, nie wymagaja dodatkowych taczników Ich eliminacia może przynieść korzyści ekonomiczn. Pozwala takie na uproszczenie montażu gtównie po przez ograniczenie ilości części składowych, jak i bra konieczności stosowania narzędzi. Cecha ta niewatpliwie ułatwia prosumpcje - jedna z jej form jest watśnie samodzielny montaż zakupionych przedmiotów [8] Tego rodzaju siedziska stanowią jednak znikoma czẹś rynku, oferowane są przez niszowe firmy. Obserwacja prototypów i produktów siedzisk RTA wykonanych
- it should be intuitive and take little time and effort. It user. However, these important properties cannot be obtained at the expense of complicated production because it should also be economical. This in turn involves the need to adapt the design to the right too and reduce the number of production steps. The use of material should also be moderate. It has many benefits: it lowers the price of the product, transport, and storage and makes the item more ecologsport, and storage and makes the item more ecological. Lower funterial consumption also has a positive effect on the malismis of by sees is by seeming supeficial activiles. The fact that the lack of decoration does not constitue minmallsm is observed by Janusz Kruphink: "In a specific historical situation, when a decoration or ornament overwhelmed items, maybe it was necessary to remind people tha in this way the usefulness of the items was lost. Nevertheless, it is difficult to find dislike of the "Byzantine splendour", "sybaritism" or "the triumph of form over substance" as a revelation or something specifically functionalist. However, it would be naive to think that the absence of these phenomena is enough to speak of asceticism, puritanism or minimalism" [5, p. 29]. The technical goal of the presented research is to develop an economical, highly effective and easy to manufacture frame structure for furniture. The developed solution can be useful not only for interior designers, but also artists whose imagination, as Rudolf Arnheim put it, can be described as the ability to give a new form to an old substance [1, p. 150]. The universality of the presented frame structure scheme mainly consist in the possibility of modifying the cross-sections and proportions, as well as mang cross-sections and it is possible to adapt tit to many types of funtur this, interio fun a terias, as well as those cut from placic. The $\mathrm{ma}$ terias, as well as those cut from plastic. The method und consist in creating and consider. The metypes sign and he furnure created on is basis have been sign and the furniture created on its basis have been planned in such a way that they can be manufactured ans of production, suc as a $\mathrm{CNC}$ machining centre.

\section{Structure concep}

The prototypes presented below are eligible for the RTA (ready to assemble) category. Furniture of this kind began to be popular in the second half of the nineteenth century, mainly due to technical progress, which enabled the mass production of cheap mechanical connectors [12]. Their application had a significan impact on the achieved market position of such companies as Gebrüder Thonet or IKEA, which is currently the leader in the production of self-assembly furniture. The presented prototypes, unlike most similar products of leading companies, do not require additional z materiałów drewnopochodnych bez łączników pozwala wyróżnić wiele przyczyn takiego stanu rzeczy. Przewaznie stosowane są $w$ nich różnego rodzaju przekszlalcenia zlaczy czopowych. Warunek ich rozlączności powoduje konieczność zastąpienia kleju dokładniejszym spasowaniem detali. Przyczynia się to do trudności podczas montażu. Ponadto samo precyzyjn wykonanie często okazuje się niewystarczające, ponieważ drewno może zmieniać swoje rozmiary, szczególni w poprzek włókien, w zależności od wilgotności i temperatury. Dodatkowo zlącze, ktore do poprawnego dzialania wymagało wykonania z dokładnoscią do dziesia. tych częśsi milimetra, przy niewielkim zużyciu przestani funkcjonować poprawnie.

Pierwszy prezentowany model, jak i cała kolekcja, od oźnia sie od hych mebli tego typu w kontekście wyże wealnie nie wymaga dodatkowych tạczików czy kleju. W złaczach wystepujadaky taż jest wygodny Całość nabiera sztywności po natoże niu siedziska spinajacego boki. Układ wymaga użycia co najmniej czterech cześci. Składa sie z dwóch wertyka nych elementów tworzących nogi oraz dwóch cześci poziomych - siedziska i poprzeczki. Poprzeczka łaczaca nog nadaje im określone nachylenie, prostopadłe do podło ża lub lekko pochylone. Określa również dystans miedzy nimi. Cześci te tworza układ przypominajacy wielką liter " $H$ ". Czwarty element nakłada się od góry. Otwory w nim "wykonane nie maja jednak takiego rozstawu, jak między czopami na górnych krawędziach boków. Dystans między gniazdami w siedzisku jest mniejszy o kilka milimetrów (il. 2). Powoduje to konieczność nagięcia nóg na odcinkach nad poprzeczką, przed nałożeniem siedziska. Otrzymane w ten sposób wygięcie i naprężenie bokow stołka czyni konstrukcję bardzo zwartą. Można to też opisac przy pomocy analogii do konstrukcji tradycyjne stolarskiej piły ramowej - na il. 1 jednakowymi koloram zostały oznaczone odpowiadające sobie elementy. Dzię ki odpowiednim napręzeniom geometria tego narzędzi nie zmienia się nawet podczas intensywnego użytkowa nia. Skręcany sznur naciągający wierzchołki pionowyc elementów jest częścią analogiczną do siedziska. Pozioma belka stolka jest odpowiednikiem dwoch elementów - poprzeczki i pily. Jej górna część jest ściskana, dolna z czopami o hakowym zakonczeniu rozciągana, podobnie jak rozciagany jest brzeszczot

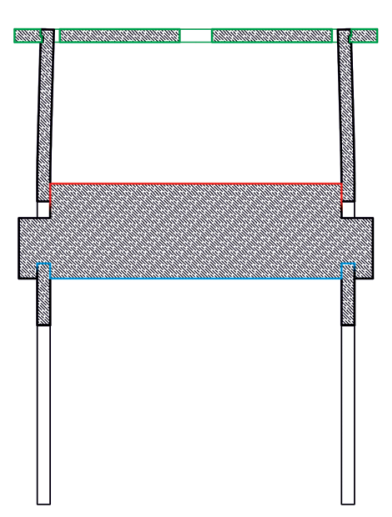

connectors. Their elimination may bring economic mainly by limiting the number of components, as well as by eliminating the need to use tools. This feature undoubtedly facilitates presumption - one of its forms is the self-assembly of purchased items [8]. However, such seats constitute a small part of the market and they are offered by niche companies. Observation of prototypes and products of RTA seats made of wood based materials without connectors allows to distinguish many reasons for this situation. Usua to distintypes of mortise and tenon joints are used in them. The condition of their disco joins are used in them. sary to replace the adhesive with a more accurate (ang ting of cetals. This contributes to a miculies during asse to be ins out to be insulficht, because the wood can change ins size, especially across the grains, depending on the humidity and temperature. In addition, the joint, whic for proper operation was produced with an accuracy of tenths of a millyention properly.

The first presented model, as well as the entire collection, is different from other furniture of this type in the context of the above-mentioned issue. The type of structure used does not really require any additional joints or glue. The joints are slightly loose, which makes them easy to assemble and disassemble. The whole structure becomes firm after laying the seat that fastens the sides. The system requires the use of at least four parts. It consists of two vertical elements forming legs and two horizonta parts - a seat and a crossbar. The crossbar joining the legs gives them a certain incline, perpendicular to the ground or slightly inclined. It also determines the distance between them. These parts form a sysmesembling the capital letter " $\mathrm{H}$ ". The fourth elche However the mortises do not have such spacing as between the tenens on the upper edges of the sides. The distance beon the millimetres aller (figure 2). This makes it necessary to berd the legs on sections above the crossbar, before as-

II. 1. Analogia konstrukciji do pity ramowej (autor: H. Albertusiak,
/Analogy to the frame saw (author: $\mathrm{H}$ Albertusiak) 
Model Still 1

Mebel odznacza się szczególnie ekonomicznym układem wykroju. Jego barzzo prosta forma zostala zaprojektowana tak, aby wycinane za pomocą frezarki CNC elementy tworzyły zwarty prostokąt. Zestaw został również dostosowany do standardowego wymiaru arkusz sklejki $(250 \times 125 \times 1,2 \mathrm{~cm})$ z uwzględnieniem kierunk słojów (il. 3). Dodatkowo proste odcinki pozwalają na sąsiadowanie krawędzi w oddaleniu o szerokości równej średnicy freza - na przykład poprzeczka na prawie całym obwodzie graniczy $w$ ten sposób $z$ wewnętrzna częścią nóg stołka. Dzięki temu wycinanie materiału oraz jego fazowanie trwa krócej, a frezarka ma mniej pracy do wykonania, co jest szczególnie istotne przy produkcj wielki . Odpow umoziliwi takż oferowanie do sprz nie meblo w plaske formie pze oferowanie do sprzedazy tów (il. 4).W tym celu na krawedziach posczególnych cześci stołka pozostawiane sa niedociete punkty, utrzymujace całość razem. Forma ta ułatwia pod wzgledem technicznym pokrycie mebla grafika za pomoca druku UV Zastosowanie takiego środka przekazu przy tym meblu jest możliwe również ze wzgledu na jego włás ciwości estetyczne. Prosty kształt i duże powierzchnie dobrze wspótistnieja z grafika artystyczna lub użytkowa.

\section{Model Still 2}

Kolejny stołek został zbudowany na tym samym układzie. Odróżnia się on od poprzedniego tym, że nie opiera się na prostokątnym, ale trapezowym kształcie. W tego typu meblach obciążenie poziome, działające na siedzisko przy zablokowanym przesuwie nóg, wy-

\section{2. Stotek Still 1 - od lewej: przekrój, zblizenie szczegótu (autor: H. A-
bertusiak)/Still 1 stool - from the left: cross-section, detail close-up (author:}

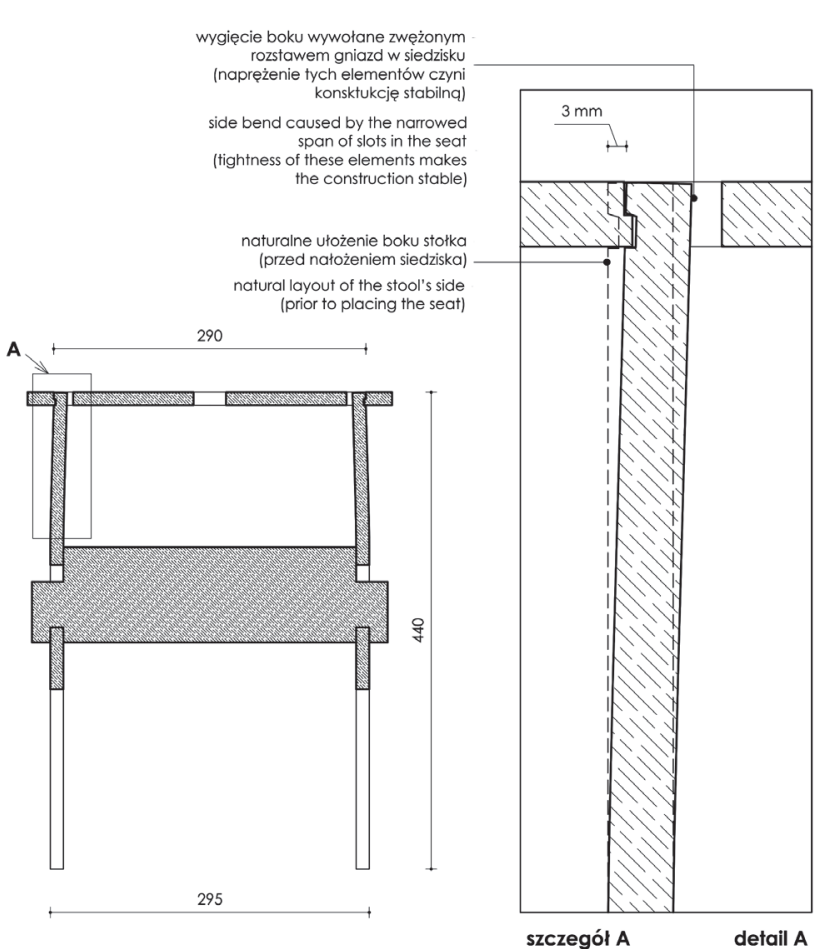

sembling the seat. Such bending and tensioning of the sides of the stool makes the structure very firm. It can also be described by analogy to the structure of a traditional frame saw - in fig. 1 corresponding elements have been marked with corresponding colours. Due to the appropriate tension, the geometry of this tool does not change even during intensive use. The twisted cord that pulls the tops of the vertical elements is a part analogous to the seat The horizontal stool bar is the equivalent of two The ments - the crossbar and the saw. Its upper pert is ench end is stretched, similarly to the blade.

\section{Model Still 1}

The furniture has a particularly economical layout. Its very simple form was designed so that the elements cut out by means of the CNC milling machine could form a compact rectangle. The set was also adapted to the standard dimension of the plywood sheet $(250$ $\times 125 \times 1.2 \mathrm{~cm}$ ), taking into account the grain direction (Figure 3). In addition, straight sections allow fo adjacent edges at a distance equal to the diameter of the milling cutter - for example, the crossbar is adjacent to the inner part of the legs of the stool on almost the whole perimeter. As a result, cutting the materia and chamfering it takes less time, and the there is less work to do with the milling machine, which is particularly important in mass production. Properly compact arrangement of elements and small waste allows also for sale of furniture in a flat form of connected elements (figure 4). For this purpose, at the edges of the individual parts of the stool there are points that were left uncut which keep the whole structure together In technical terms, this form facilitates covering the furniture with graphics using UV printing. The use of such mean for this furite is a possible due to measure fo gowell with aatistic simplied graphics.

\section{Model Still}

Another stool was built on the same layout. Contrary to the previous one, this model is not based on a rectangular shape, but on a trapezoidal one. In this type of furniture, the horizontal load imposed on the seat with the blocked leg movement causes the frame to work however, the bending is smaller than in the stools with vertical legs [4]. This translates into the possbility of reducing the cross-sections of the legs and cross-bars, and consequently reducing the weight. The furniture was made of a bilaterally laminated MDF board, $12 \mathrm{~mm}$ thick. Such a material makes it possible to avoid the varnish process - it is sufficient to cove the edge with wood impregnating oil.

In order to reduce the amount of material waste, when cutting furniture using a CNC milling machine, the side elements forming the legs of the stool were

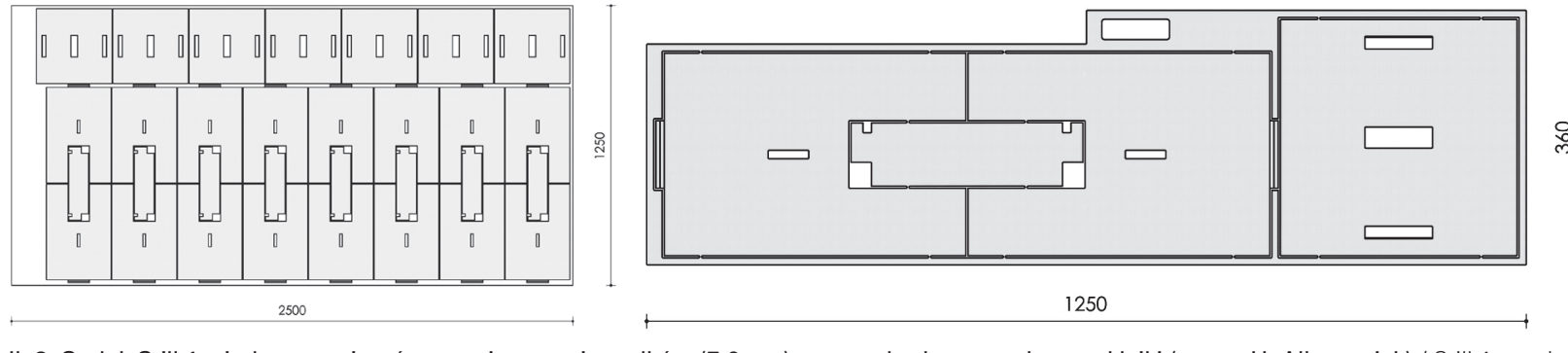

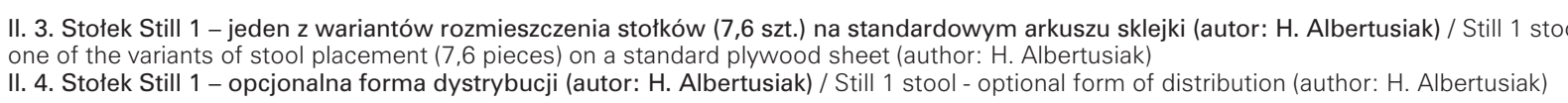
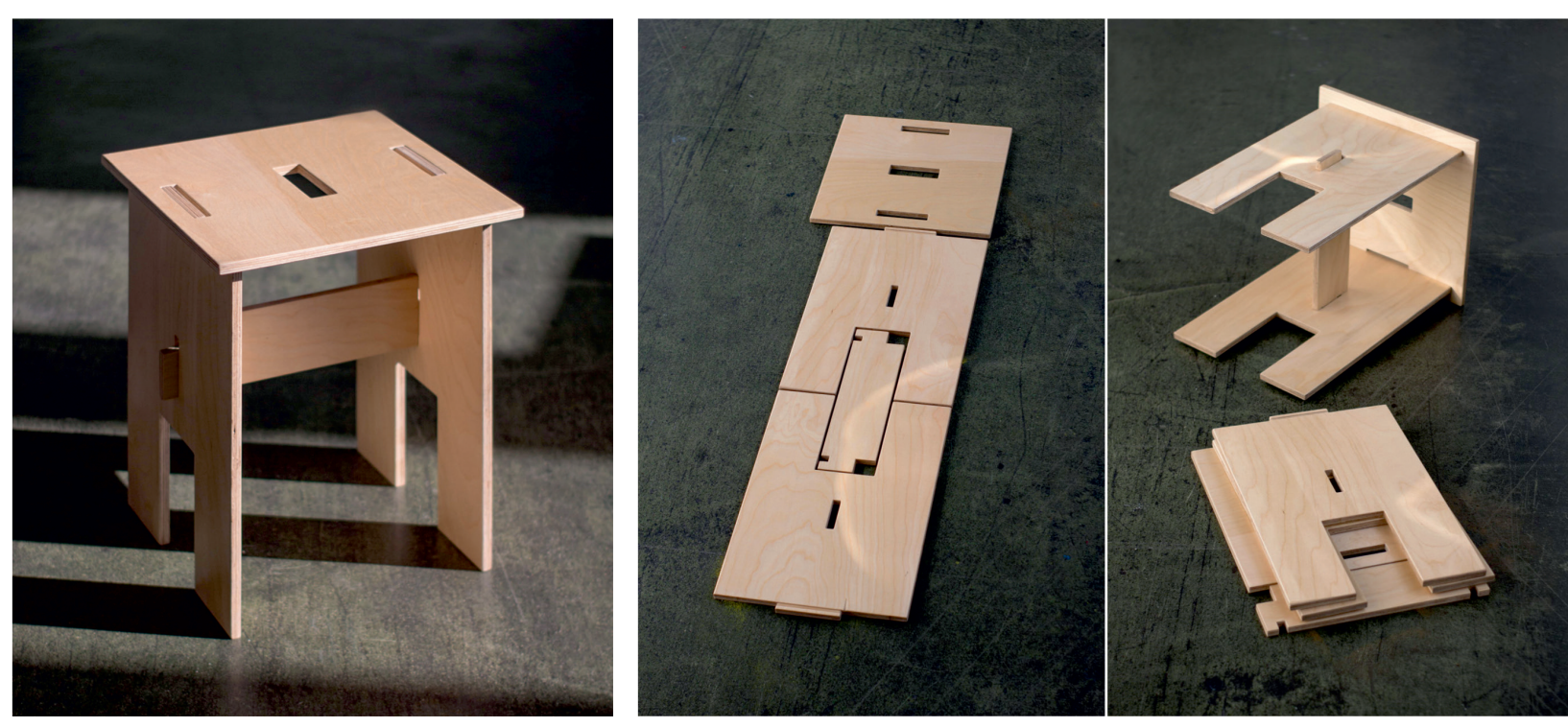

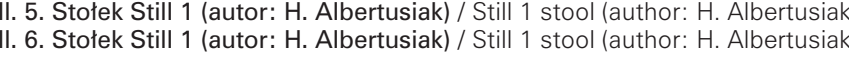

wołuje ramową pracę szkieletu, ale zginanie to jes mniejsze niż w taboretach z nogami pionowymi [4]. Przekłada się to na możliwość zmniejszenia przekrojów nóg i poprzeczek, a w konsekwencji redukcję wagi. Me bel został wykonany z laminowanej dwustronnie płyty MDF o grubości $12 \mathrm{~mm}$. Taki materiał pozwala uniknąc procesu lakierowania - wystarczające jest pokrycie kraweedzi impregnującym olejem do drewna. W celu mebla za polos frezarki CNC boczn, przy wycinaniu mabla za pomoca frezadu mach boc doenty twozżyciu połaczeń lom siedziska jest niewielki cieziar i mozliwó́c sztaplowaszybkiego użycia.

\section{Model Still 3}

Still 3 bazuje na konstrukcji analogicznej do drugiego modelu. Od poprzednika najbardziej odróżnia go materiał, z którego zostało wykonane siedzisko. Jest ono wycięte $z$ arkusza litego polipropylenu o grubości $3 \mathrm{~mm}$ w którym wyfrezowano linie umożliwiajace jego zginanie. Zestawienie materiałów $w$ tym modelu jest $w$ petni zgodne z ich właściwościami. Drewno, które naturalnie dobrze nadaje się do konstrukcji szkieletowych, zostało connected from two parts using biscuit joints (ill. 8). An important advantage of the seat is the light weight and the possibility of stacking, facilitating the storage of furniture ready for quick use.

\section{Model Still 3}

Still 3 is based on a structure analogous to the second model. It differs from the previous mode mostly as regards the material from which the seat was ma it is cut from a $3 \mathrm{~mm}$ thick polypropylen whet, in which lines we milled to allow it to be ul wich

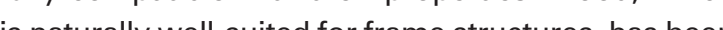
supplem to cre a relavely materian that makes it possible As in previous vers lange and llexible seat surface. As in previous versions, it fastens the sides together, A structure. The material is put into the side part of the legs and it remains in this place firmly (ill. 11). The projections do not tend to fall out of the mortises and perfectly resist the shearing force acting on them. The stool can also be stacked. bent The combintion of male 


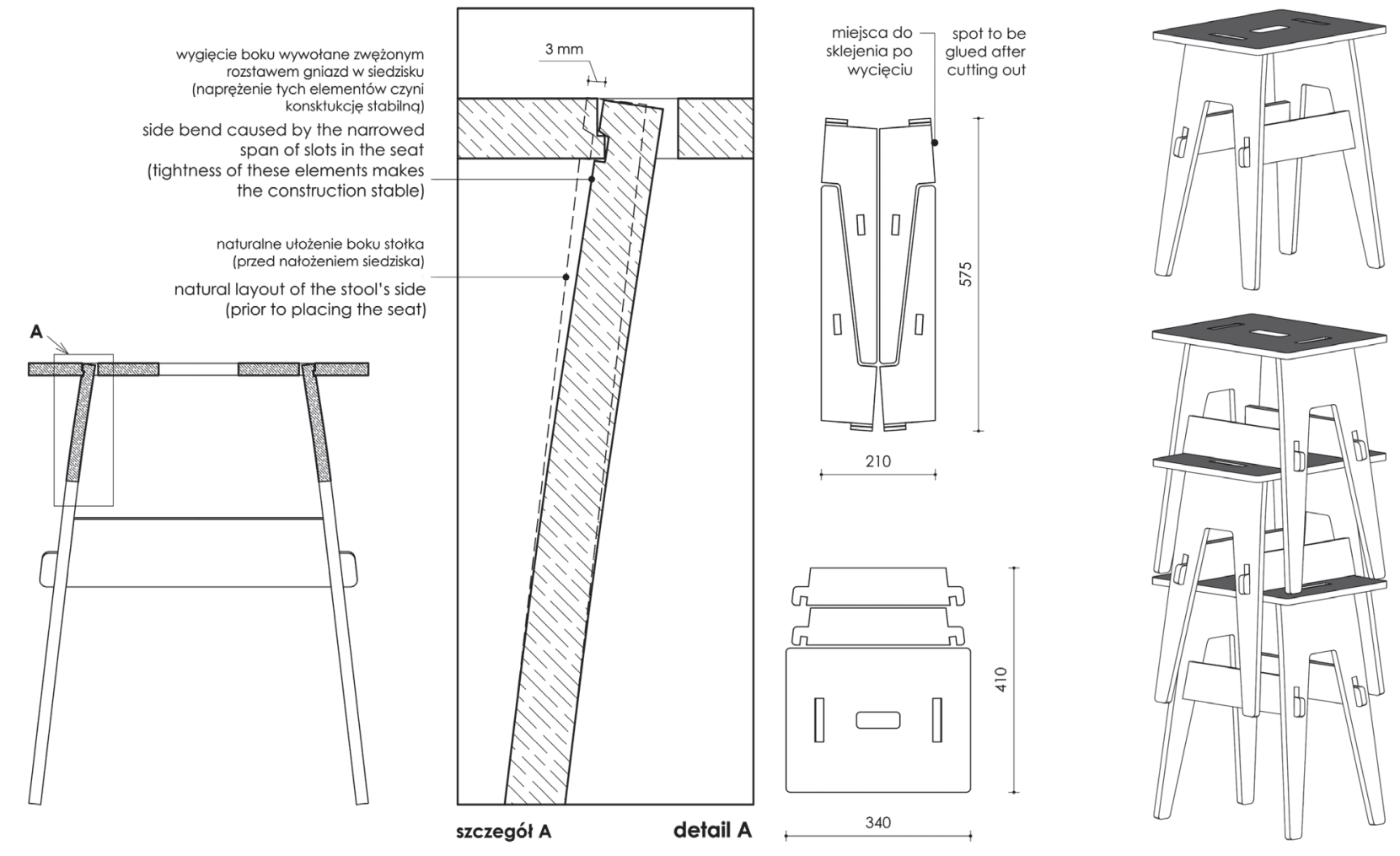

II. 7. Stołek Still 2 - od lewej: przekrój, zbliżenie szczegółu (autor: H. Albertusiak) / Still 2 stool - from the left: cross-section, detail close-up II. 8. Stotek Still 2- od lewej: rozmieszczenie elementów do wykroju, schemat sztaplowania (autor: H. Albertusiak) / Still 2 stool - from the left:
arrangement of elements for cutting, stacking pattern (author: $H$. Albertusiak)
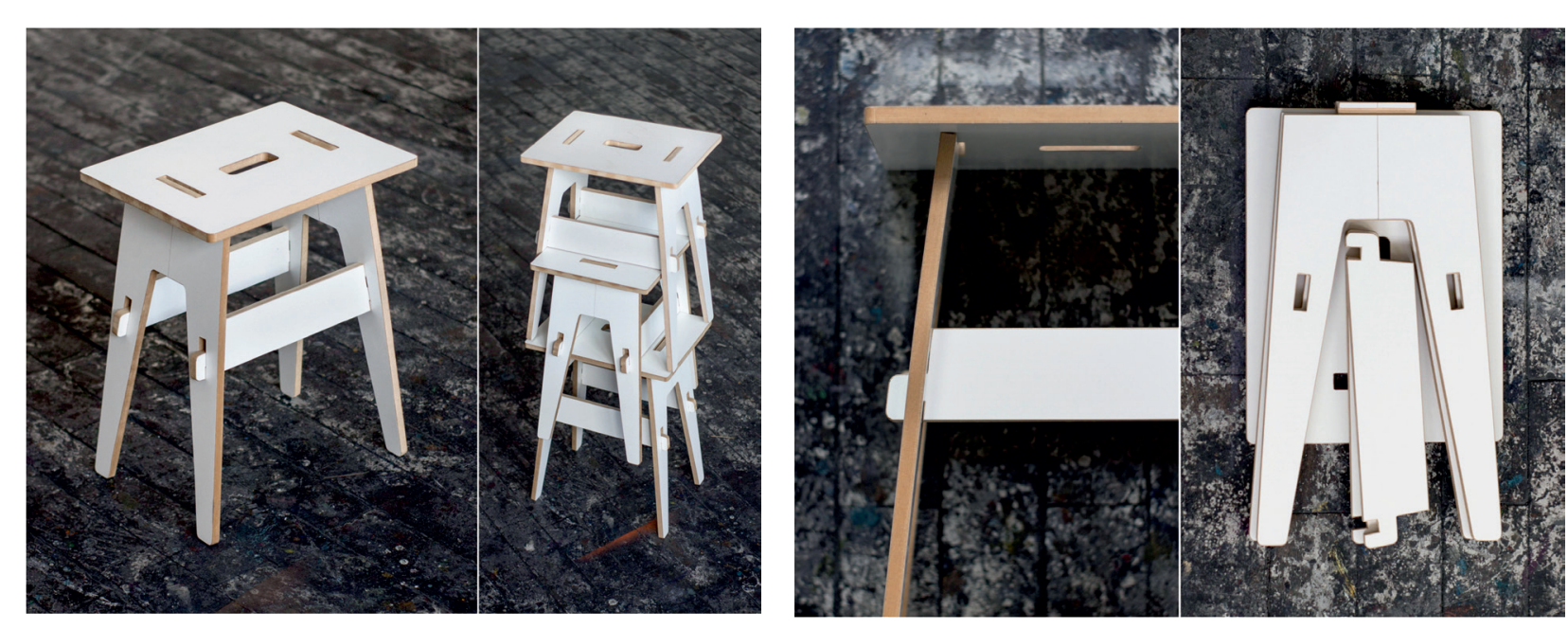

II. 9. Stotek Still 2 (autor: H. Albertusiak) / Still 2 stool (author: H. Albertusiakk
II. 10. Stotek Still 2 (autor: H. Albertusiak) / Still 2 stool (author: H. Albertusiak)

uzupełnione tworzywem, pozwalającym stworzyć z niego stosunkowo dużą i giętką płaszczyznę siedziska. Podobnie jak we wcześniejszych wersjach, spina ono boki razem, generując $w$ ten sposób naprężenie stabilizujące całość. Tworzywo wsuwane jest w boczną część nóg i tkwi w tym miejscu stabilnie (il. 11). Wypusty nie maja działającej na nie sile ścinającej. Stołek również można sztaplować.
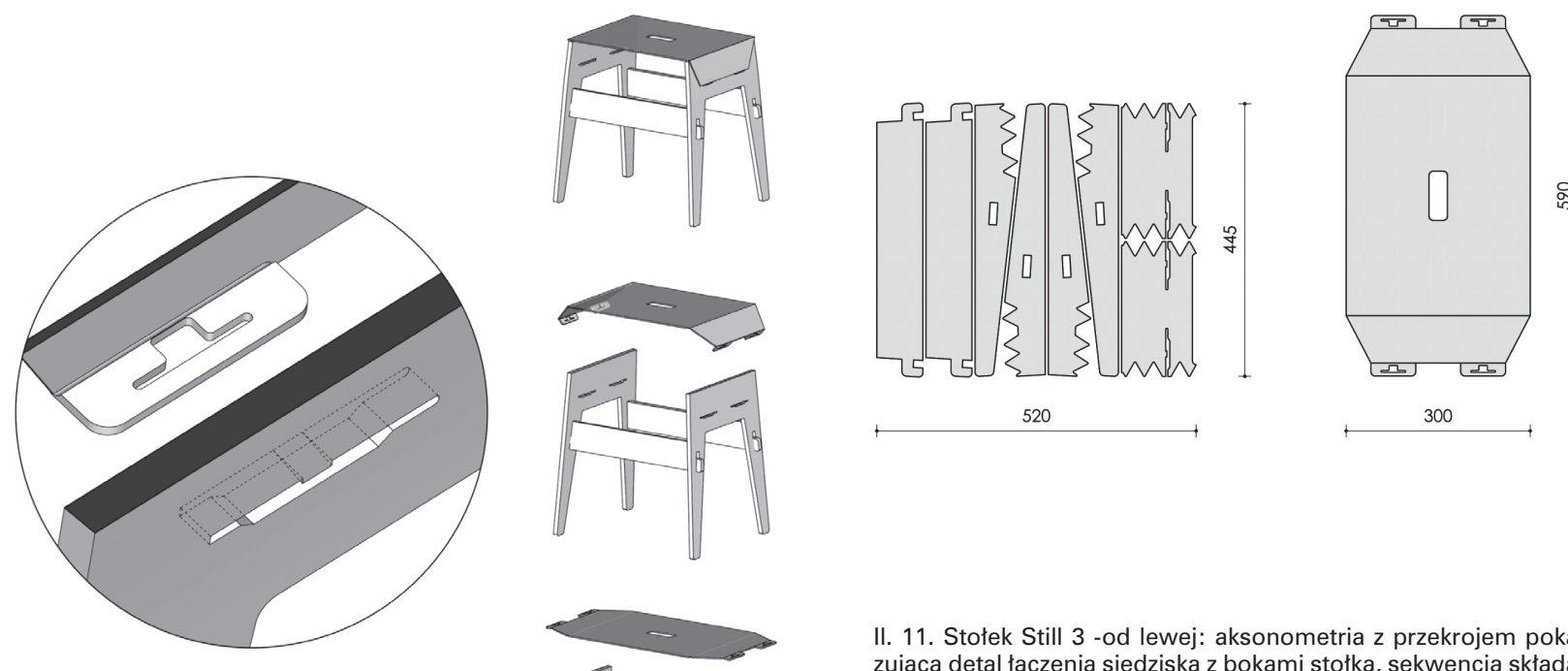

300

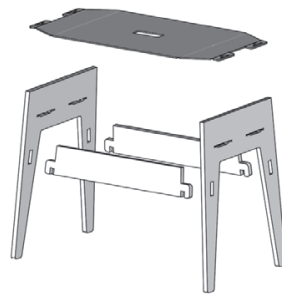

11. 11. Stotek Still 3 -od lewej: aksonometria z przekrojem pokania stotka (autor: H. Albertusiak) / Still 3 stool - axonometry wi a cross-section showing the detail of connecting the seat with the
sides of the stool, the sequence of stool folding lauthor: 4 A

II. 12. Stotek Still 3- rozmieszczenie elementów do wykroju (au-
tor: H. Albertusiak) / Still 3 stool - arrangement of elements for curt H. Albertusiak / Still 3 stool - arrangement of elements for
cutting (author: H. Albertusiak)
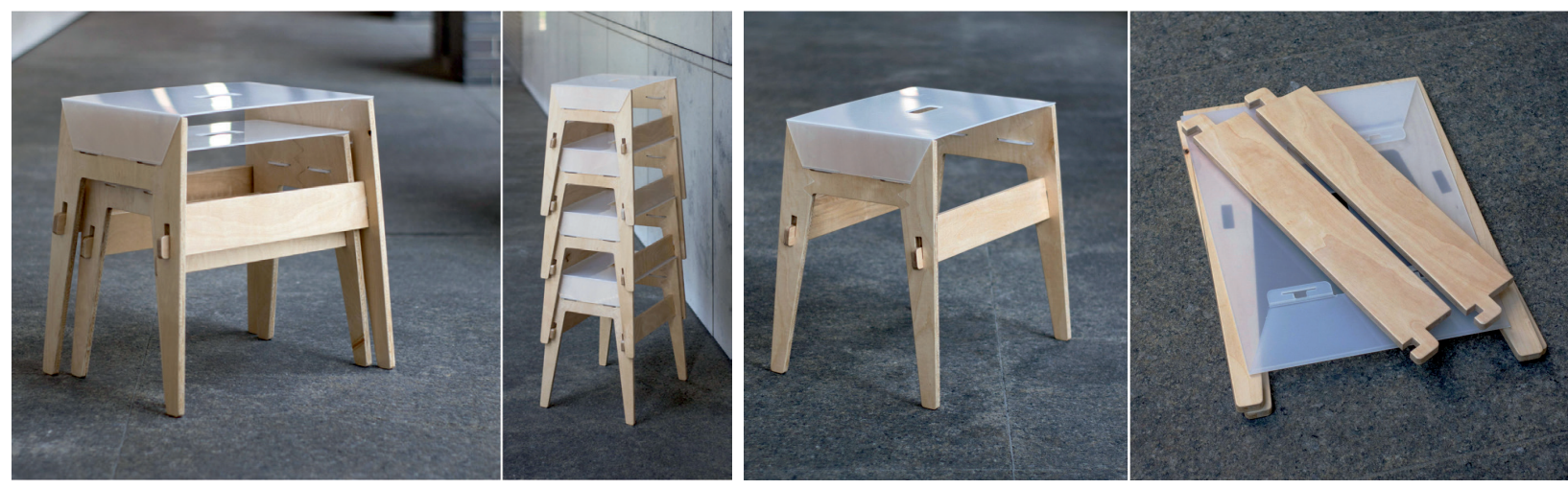

II. 13. Stotek Still 3 (autor: H. Albertusiak) / Still 3 stool (author: H. Albertusiak)
II. 14. Stotek Still 3 (autor: H. Albertusiak) / Still 3 stool (author: H. Albertusiak)

Krzesło Still K1

Ostatni mebel z prezentowanej kolekcji to krzesło. tym przypadku opracowany wcześniej typ konstrukcj zostal zastosowany w dwóch wiejscach i nadal stanow jedyny sposob ksztaltowanha formy. Tego rodzaju kon-

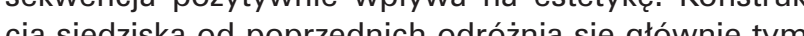

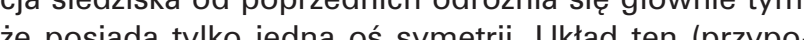
minajey poprzednie stotki) zostal oddzieny (prypooparcia trójkatnym wcieciem. Zapewnia to możliwośc ściśnięcia jego boków w celu montażu polipropyleno wego arkusza. Poza tym wglebienie to spetni jeszcze dwa zadania. Pozwala na efektywniejsze sztaplowanie (il 16) poniewaz tylna poprzeczka nakładanego od góry siedziska znajduje w nim miejsce. Oddzielenie to daje również możliwość niezależnego napreżenia ramy do mocowania oparcia. Dzięki temu wygieccie jej pionowych elementów ma miejsce wyżej niż wygiẹcie boków siedziska i może zostać niezależnie uformowane. Kształt symmetry. This layout (which is similar to the previous stools) was separated from the frame by a triangular indentation. This ensures that its sides can be clamped to assemble the polypropylene sheet. In addition, the indentation has two more purposes. It allows for more efficient stacking (ill. 16), be cause the rear crossbar of the top seat is located in it. Moreover, this separation gives the possibility ing the backrest. Due to this, its vertical elements are bended higher than the sides of the seat an above-described detail results from the fulfilment of a number of tasks, without hindering the productio of furniture and its use. It also positively influences the form of the chair, gives it dynamics, and makes it different from the stereotypical layout of a chair. This combination of structural, functional and aesof independent tensioning of the frame for attachit can be independently formed. The shape of the 

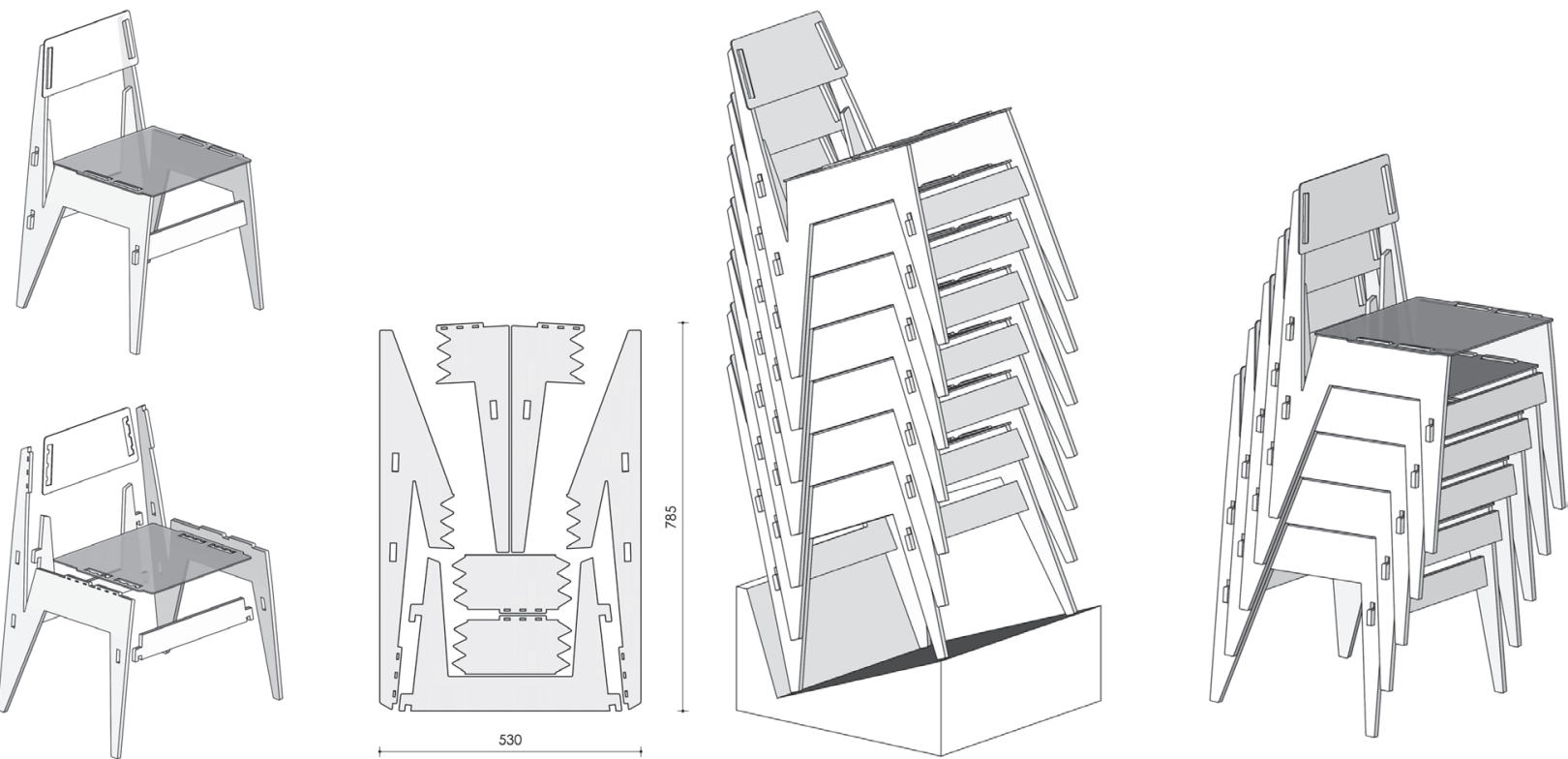

II. 15. Krzesto Still A1 - od lewej: sekwencja skladania krzesta, przykładowy rozkrój elementów ze sklejk
from the left: the chair folding sequence, exemplary layout of plywood elements (author: H. Albertusiak)

II. 16. Krzesto Still A1 - od lewej: sztaplowanie na stojaku, sztaplowanie zwykte (do 5 sztuk) (autor: H. Albertusiak) / Still A1 chair - from the left
stacking on the stand, regular stacking ( (up to 5 pieces) (author. $H$. Albertusiak)
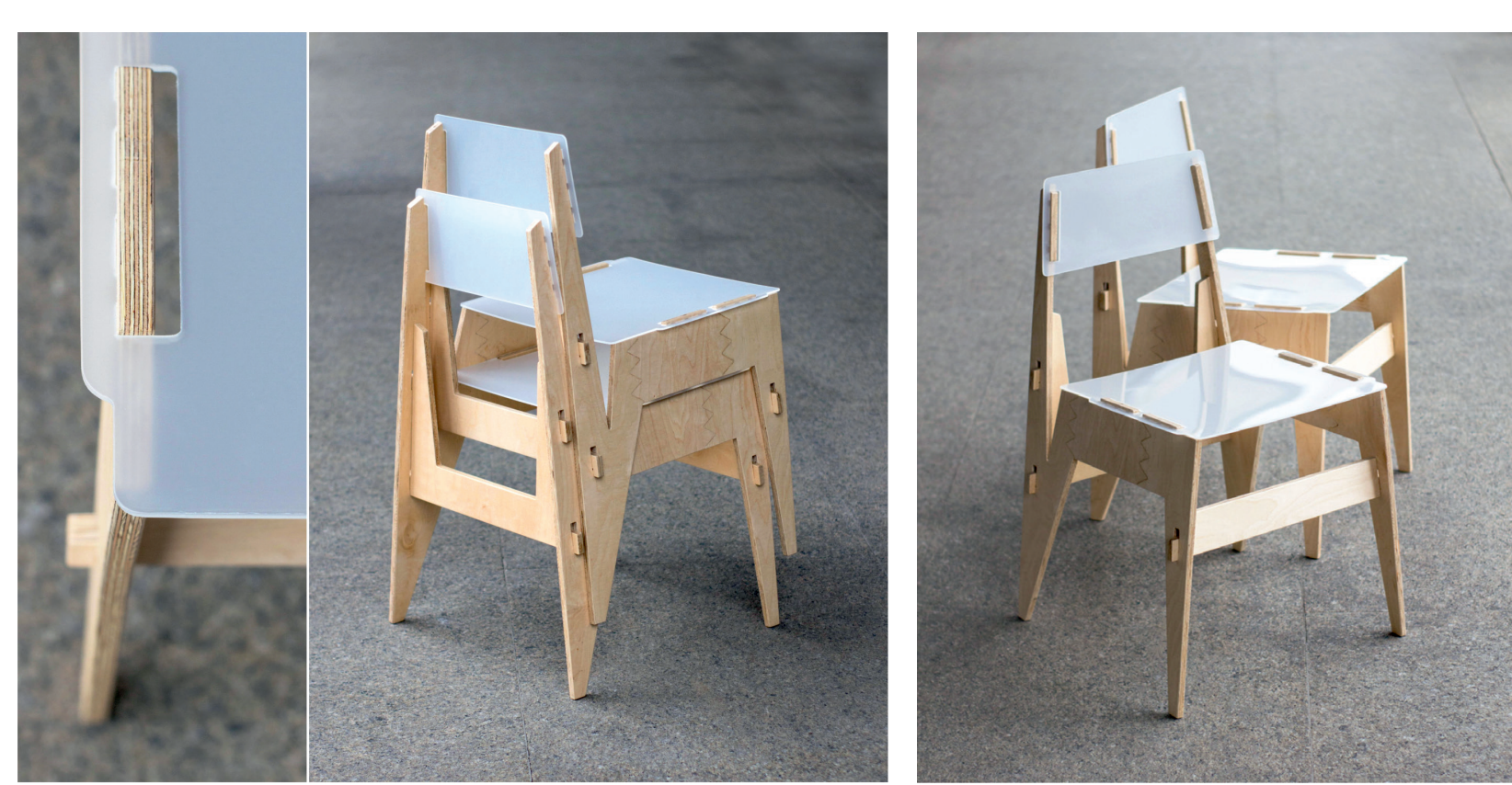

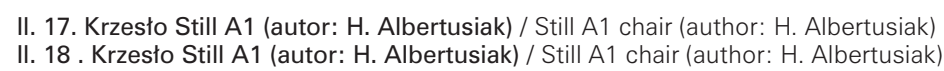

opisanego powyżej detalu wynika ze spełniania szeregu zadań, nie utrudniaiac przy tym wytwarzania mebla oraz jego użytkowania. Pozytywnie wpływa również na formę, nadaje dynamiki i stanowi odstepstwo od stereotypowego układu krzesła. Takie połączenie atutów konstrukcyjnych, użytkowych i estetycznych w jednym rozwiązaniu może stanowić przykład właściwego działania projektowego.
Podsumowanie

Nadrzędną wartościa zaprezentowanych powyzej dzialan jest opracowany typ konstrukcji. Został on z powodzeniem zastosowany do budowy stolka o konstrukcji deskowej, jak i stołków i krzesla o konstrukcji szkieletowej. Zróżnicowanie to świadczy o szerokich możliwościach jego modyfikacji i zastosowań. Obiekty te nie powinny byc rozpatrywane jako gotowe produkty, ale prototypy, ukazujące potencjał opracowanego rozwiazania. Każdy z nich wytrzymuje obciążenie użytkownika o wadze do $110 \mathrm{~kg}$. Przez dwa lata doświadczały sporadycznego użytkowania - każdy egzemplarz był używany łaccznie przez kilkadziesiąt godzin. Prezentowano je takze na wielu targach i wystawach, gdzie testowali je potencjal podbory. Co istotne, przez wiekszosc cza poly przertymo co wimo sta wystepiacego w nie napre zenia, nie stracita swoich wháciuści. Niewatpliwytutem tego układu ject również możliwość jego skła dania/rozkładania. Zaznajomiona z przedmiotem osoba może uczynić to w czasie wynoszacym od kilkunastu do czterdziestu sekund, w zależności od modelu. Cze ści każdego mebla po rozmontowaniu można utożc w płaska sterte której wysokość nie przekroczy kilku centymetrów. Taka kompresja przynosi oczywiste kocentymetrow. Taka kompresja przynosi oczywiste kogazynowanie, jak $\mathrm{i}$ transport. Oszczędności wynikaj także z niewielkiego zużycia materiału (np. krzesło Still $K 1$ waży $3 \mathrm{~kg}$ ). Zmniejszenie ilości odpadu poprodukcyjnego zapewnia odpowiednio zaprojektowany rozkró elementów. Został on zaplanowany w taki sposób, aby duże lub mało ustawne elementy podzielić, a po wykrojeniu skleic przy użyciu połączen na wczepy klinowe. Dzięki powyższym czynnikom mebel może zostac zakwalfikikowany do tych wyprodukowanych zgodnie $z$ ideą zrównoważonego designu, ktora powoli staje sie standardem. "Ograniczenie zužycia surowców, energ oraz ilości odpadów przy produkcji nowego produk tu" to według Artura Borcucha pierwsza z trzech dró do tego prowadzących [2, s. 96]. Istotne oszczędnośc (w przypadku wdrozenia tego typu mebla do produkcji seryjnej) mogiyby zostac osiągnięte dzięki zamianie echniki wytwarzania siedzisk i oparc. Te pokazane $n$ zdjęciach zostaly wykrojone $z$ arkusza polipropylenu 1 tego, przy użyciu centrum obrobczego CNC. Zmiana tej technie na reduc wo wadzenie ulepszeń projektu poprzez ukrycie potaczen wre krawedzi. Wtaściwe byłyby również warianty z tapicerowanymi Wementami. Wnioski ptynace z tych obserwa świadcza o potencjale wdrożeniowym koncepcii konstrukcyinej.

Peter Zumthor napisał: „[...] niewiele jest architektonicznych problemów, dla których nie znaleziono by juz wcześniej rozstrzygających rozwiązań" [14, s. 22-23]. Świadomość tej sytuacji jest dla projektanta bardzo istotna. Jedno z najpopularniejszych obecnie krzeset (za równo w przestrzeniach prywatnych, jak i publicznych)DSW autorstwa Charlesa i Ray Eames'ów - wprowadzo- of frame structure. This differentiation indicates the tions. These objects should not be considered as finished products, but as prototypes showing the potential of the developed solution. Each of them can withstand a user load of up to $110 \mathrm{~kg}$. For two years they have been used sporadically - each copy has been used for several dozen hours in total. They were also presented at many trade fairs and exhibitions, where they were tested by potential exsibmers. Importantly, most of the time they were kept in a redy-to-use form, and the structure, despite in An unquestionable advantage of this structure is the possibility of its folding/unfolding. A person that has done it before can do it within ten to forty seconds, depending on the model. Parts of each piece of furniture after disassembling can be arranged in a flat heap, the height of which does not exceed few centimetres. Such compression brings obvious utility benefits, but it is also economically ad vantageous, as regards storage and transport. Sav ings also result from low material consumption (e.g. the Still $K 1$ chair weighs $3 \mathrm{~kg}$ ). The reduction of the amount of post-production waste is ensured by the appropriately designed cutting of elements. It has been planned in such a way as to divide the large or non-flexible elements, and, after cutting, glue them using the finger joints. Due to the above factors, the furniture can be qualified to those produced in accordance with the idea of sustainable design, which is slowly becoming a standard. According to Artur Borcuch, "limiting the consumption of raw materials, energy and the amount of waste in the production of a new product" is the first of three paths leading to sustainable design [2, p. 96] Substantial savings (in the case of the implementation of this type of piece of furniture for mass production) could be achieved by replacing the technique the anes shown in velid polypropya ing this techique to the PP injection method word allow even greator reduction of waste. It wold low eve ments by hiding condion or design inproveor thickening cond holsered elemer hols conclusions from these observations indicate the

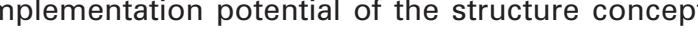

Peter Zumthor stated: "[...] there are not many archiectural problems for which no conclusive solution could be found" [14, p. 22-23]. Awareness of this situation is very important for the designer. One of the most popular chairs today (both in private and public spaces) - DSW by Charles and Ray Eames - 
no na rynek w 1950 roku. Siedzisko to, jak i wiele innych popularnych wznowień, mimo upływu lat stanowi w pełni funkcjonalny przedmiot. Co więcej, komponuje się ze współczesnymi wnętrzami i architekturą nie jako historyczny akcent, ale spójny stylistycznie i ideowo element. Ewolucja otoczenia człowieka, napędzana postępem technicznym, dotyczy wielu rodzajów mebli ze względu na usprawnienia produkcji. Opisane realia stanowią uzasadnienie charakteru przedstawianej serii prototypów, które podobnie jak krzesło DSW [13], zostały zaprojektowane jako tanie meble. Ich forma nie jest awangardowa, są to zwyczajne stołki meble tego rodzaju towarzyszą człowiekowi od kilku tysięcy lat i prawdopodobnie jeszcze długo tak będzie. Ważną cechą koncepcji jest odpowiednie dostosowanie konstrukcji do współczesnych realiów i środków produkcji. Realizacja tego celu nie zaowocowała więc unikatową formą, ale w pewnym stopniu uczyniła meble innowacyjnymi.

\section{LITERATURA}

[1] Arnheim R., Sztuka i percepcja wzrokowa. Psychologia twórczego oka, Wydawnictwa Artystyczne i Filmowe, Warszawa 1978 [2] Borcuch A., Ekonomia designu. Wydanie II, CeDeWu Sp. z o. o., Warszawa 2017

[3] Botton A., Architektura szczęścia, Wydawnictwo Czuły Barbarzyńca, Warszawa 2010

[4] Kozikowska A., Forma a konstrukcja mebli. Meble o konstrukcji belkowej oraz ramowej [online], http://aeawa.pb.edu.pl/wpcontent/uploads/2018/08/Architektura-4-2010-do-internetu-8.pdf (dostęp: 04.07.2019)

[5] Krupiński J., Funkcjonalizm - teoria architektury i designu. Krytyka podstawowych założeń [online], https://krupinski.asp.krakow. pl (dostęp: 28.06.2019)

[6] Loos A., Adolf Loos Ornament i Zbrodnia - Eseje wybrane, Wydawnictwo BWA, Tarnów 2013

[7] Mielnik A., Współczesne tendencje minimalistyczne w architekturze domów jednorodzinnych. Część pierwsza [online], http:// www.pif.zut.edu.pl//images/pdf/pif-16_pdf/B-09_Mielnik.pdf (dostęp: 11.07.2019)

[8] Murawska A., Długosz H., Prosumpcja jako forma aktywności konsumentów na rynku dóbr i usług [online], https://bazybg.uek. krakow.pl/bazekon/zawartosc/171530076 (dostęp: 08.07.2019)

[9] Papanek V., Dizajn dla realnego świata, Wydawnictwo Recto Verso, Łódź 2012

[10] Paul Kasmin Gallery [online], https://www.kasmingallery. com/_data/fa6029a16a356268badf039493bd864b.pdf (dostęp: 27.06.2019)

[11] Rybczyński W., Dom. Krótka historia idei, Wydawnictwo Karakter, Kraków 2015

[12] Sydor M., Ligocki M., O tącznikach w meblach do samodzielnego montażu (RTA) [online], https://fastener.pl/archiwum\%5bwy danie,41081,1,2018,41138\%5d\#41138 (dostęp: 08.07.2019)

[13] Vitra [online], https://www.vitra.com/en-hu/product/eamesplastic-chair (dostęp: 25.06.2019)

[14] Zumthor P., Myślenie architekturą, Wydawnictwo Karakter, Kraków 2010 was launched in 1950. Despite the passage of time, this seat, as well as many other popular renewals, has been a fully functional object.

What is more, it matches contemporary interiors and architecture not as a historical accent but a stylistically and ideologically coherent element. The evolution of the human environment, fuelled by technical progress, concerns many types of furniture due to the improvement of production. The described reality justifies the nature of the series of prototypes presented, which, similarly to the DSW chair [13], have been designed as cheap furniture. Their form is not avant-garde, they are ordinary stools - this type of furniture has been accompanying people for several thousand years and it will probably continue to be this way for a long time. An important feature of the concept is the appropriate adaptation of the structure to contemporary reality and means of production. The implementation of this objective did not result in a unique form, but to some extent made the furniture innovative.

\section{BIBLIOGRAPHY}

[1] Arnheim R., Sztuka i percepcja wzrokowa. Psychologia twórczego oka, Wydawnictwa Artystyczne i Filmowe, Warszawa 1978

[2] Borcuch A., Ekonomia designu. Wydanie II, CeDeWu Sp. z o. o., Warszawa 2017

[3] Botton A., Architektura szczęścia, Wydawnictwo Czuły Barbarzyńca, Warszawa 2010

[4] Kozikowska A., Forma a konstrukcja mebli. Meble o konstrukcji belkowej oraz ramowej [online], http://aeawa.pb.edu.pl/wp-content/uploads/2018/08/Architektura-4-2010-do-internetu-8.pdf (access: 04.07.2019) [5] Krupiński J., Funkcjonalizm - teoria architektury i designu. Krytyka podstawowych założeń [online], https://krupinski.asp.krakow.pl (access: 28.06.2019)

[6] Loos A., Adolf Loos Ornament i Zbrodnia - Eseje wybrane, Wydawnictwo BWA, Tarnów 2013

[7] Mielnik A., Wspótczesne tendencje minimalistyczne w architekturze domów jednorodzinnych. Część pierwsza [online], http://www.pif.zut. edu.pl//images/pdf/pif-16_pdf/B-09_Mielnik.pdf (access: 11.07.2019)

[8] Murawska A., Długosz H., Prosumpcja jako forma aktywności konsumentów na rynku dóbr i usług [online], https://bazybg.uek.krakow.pl/bazekon/zawartosc/171530076 (access: 08.07.2019)

[9] Papanek V., Dizajn dla realnego świata, Wydawnictwo Recto Verso, Łódź 2012

[10] Paul Kasmin Gallery [online], https://www.kasmingallery.com/_data/ fa6029a16a356268badf039493bd864b.pdf (access: 27.06.2019)

[11] Rybczyński W., Dom. Krótka historia idei, Wydawnictwo Karakter, Kraków 2015

[12] Sydor M., Ligocki M., O łącznikach w meblach do samodzielnego montażu (RTA) [online], https://fastener.pl/archiwum\%5bwydanie,41081 ,1,2018,41138\%5d\#41138 (access: 08.07.2019)

[13] Vitra [online], https://www.vitra.com/en-hu/product/eames-plastic-chair (access: 25.06.2019)

[14] Zumthor P., Myślenie architekturą, Wydawnictwo Karakter, Kraków 2010 